\title{
Employee Engagement and Organizational Performance of Public Enterprises in Nepal \\ Rupa Shrestha*
}

\begin{abstract}
Background: Employee Engagement' has been a considerable topic in the public sector. It is a buzz word that managers think they understand, but face difficulties and challenges while practicing.

Objective: This study aims that employee engagement impacts on organizational performance in some extent. Drawing on theory "Employee Engagement and Higher Work Ethic, (The Gallup Organization, 2013), this study examines the relation between employee engagement and organizational outcome.

Methodology: Based on descriptive analysis, this study consisted officer level employees from Tribhuvan University from 49 campuses and offices as respondents. The data was collected through 115 set of structured questionnaires during last three months of 2075 BS and It used descriptive and inferential statistics tools to analyze the data.

Result: It was hypothesized that the employee engagement was positively related to the organizational performance with liking of work force diversity. It is revealed that majority employees of TU are engaged with work and organization as well. During the analysis, the hypothesis was supported with $0.505 \mathrm{r} 2$ (50 percentages). It was also found that explanatory and dependent variables are correlated with 0.696.

Conclusion: It can be concluded that there is significant relation between organizational performance and employee engagement. Employees, who are engaged with jobs can understand social cues among the others thus they can choose the way to improve social skills in order to achieve organizational goals. This study also complies that the relation between employee engagement and performance is diverse as per work force patterns in work place.

Implication: This research stimulates researchers to begin to think about how employee engagement relates to $H R$ and organizational outcome. Public enterprises should always try to make employees engaged and transform not engaged and disengaged employees to engaged ones which ultimately leads to enhance organizational culture.
\end{abstract}

Key Words: Employee Engagement, Organizational Performance, Work force Diversity

${ }^{*}$ M.Phil, Faculty of management, Tribhuvan University, Nepal, corresponding

Email: shrestharupa06@gmail.com 


\section{Introduction}

Gallup Incorporation, a consultant firm has made significant contribution on measuring employee engagement and the Q12 model suggested by it is a commonly used worldwide. Various other academic and practitioners are also engaged in measuring it through the use of different model in their respective organization and the nation. However, not much more work is done regarding Nepalese context and thus, this paper attempts to measure engagement level of Nepalese employees working in media sector.

In public enterprises, to provide rapid and efficient service to the citizens, Government of Nepal has appointed so called highly skilled and qualified HR time by time. However, the bureaucratic system is not getting the exact shape and providing the satisfactory service. Likewise, the private sector is also suffering from the same problem in terms of customer service and other business performance outcomes. In order to overcome from this reality, the employee engagement approach and its study is useful. It is because, according to (Little \& Little, 2006) the items used in employee engagement surveys measure aspects of the workplace that are under the control of the local manager.

Since that, according to (Soni, 2013) 'Employee Engagement' has been a hot topic in the corporate circles. It is a buzz word that employers think they understand, but face difficulties and challenges while practicing. Many organizations copy 'Employee Engagement' activities from the best practices, looking at the benefits enjoyed by their competitors? However, most lose track after a few strides ahead. 'Employee Engagement' cannot be a cosmetic intervention in enhancing commitment towards job, motivation or productivity. Corporate culture has an important role in enduring positive impact of such engagement programs."

Engagement is a workplace approach designed to ensure that employees are committed to their organization's goals and values, motivated to contribute to organizational success, and are able at the same time to enhance their own sense of well-being (MacLeod \& Clarke, 2009). Rothwell, (2010) described engagement as a positive attitude toward the job and distinguished it from both job satisfaction and commitment. Thus, the complete equation of engagement is obtained by aligning maximum job satisfaction and maximum job contribution (Sharma \& Krishnan, June 2012). In the light of these constructs, work engagement is identified as highly involved in helping employees become more deeply engaged with their work and reduce the effect of job burnout. To wrap up our core argument for employee engagement, research by a number of scholars (Fleck and Inceoglu, 2010; May et al., 2004; Saks, 2006; Shuck and Reio, 2011) suggests that engaged employees are more likely to outperform disengaged employees.

It is often stated that the level of employee engagements is being used and also the type of employee engagement being used, would be studied over time. It is likely that level of 


\section{Statement of the Problem}

employee engagement of existing employee impacts more often to enhance organizational performance very well. Such type of research has certain gap in public sector service thus this in turn leads to my central problem of statement:

How employee engagement impacts on organizational performance? The relation between the use of employee engagement and organizational performance are studied over time with looking moderating effect of workforce diversity.

\subsection{Conceptual Framework}

This study is based on this conceptual framework employee engagement as explanatory variables and its impact on organizational performance as relative variable and relation of these variables may moderate by work force diversity of an organization.

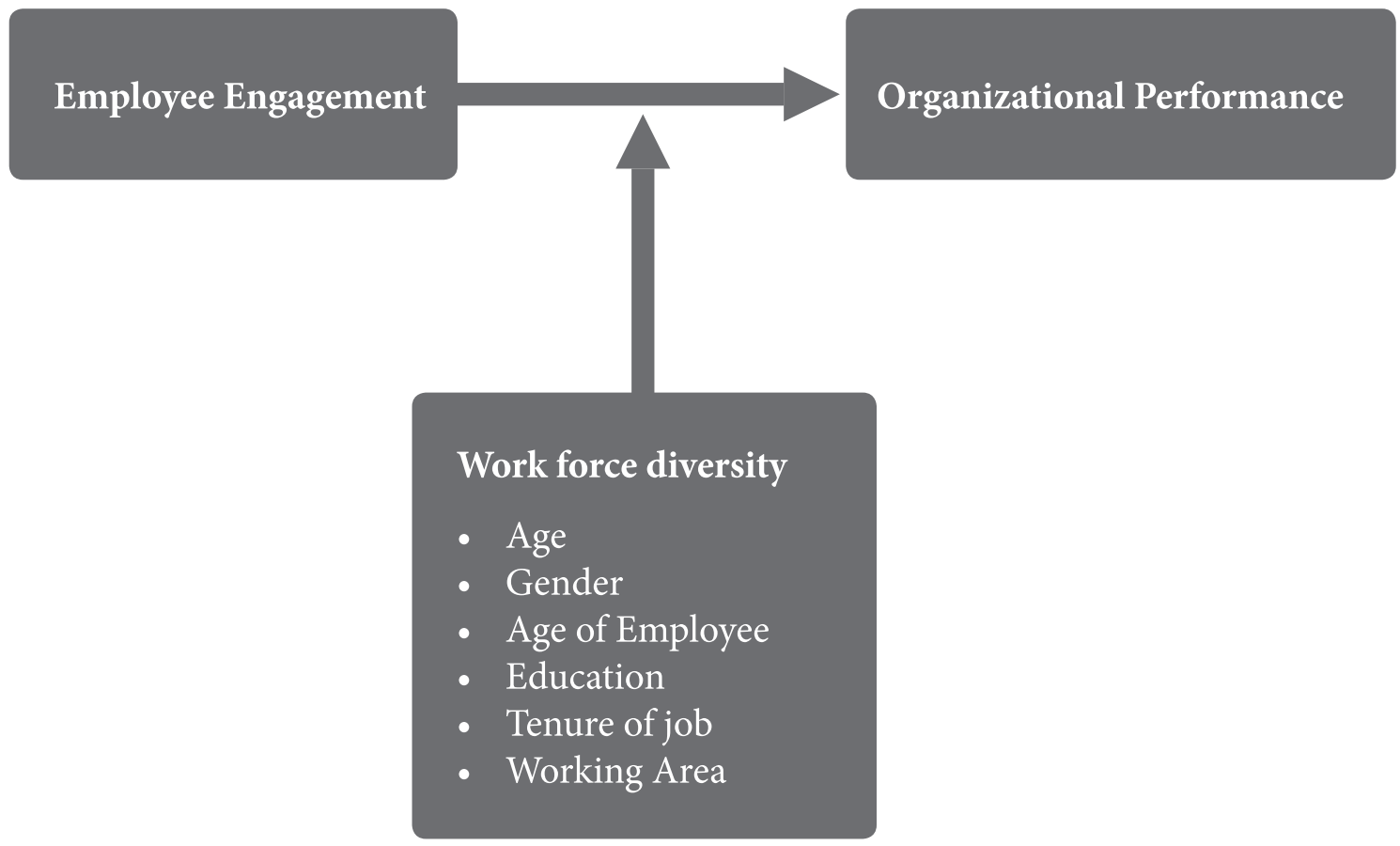

\subsection{Objectives of the Study}

This study conceptualized employee engagement and its impact on organizational positively on the basis of different work force diversity. Generally this study concerned with following main purposes. 
1. Investigate how employee engagement influences the organizational erformance.

2. Analysis in what extent the work force diversity factors moderate the elationship between employee engagement and organizational performance.

\subsection{Research Hypothesis}

Based on literature review and research problem the following hypothesis are formulated that may help to find out the weather employee engagement and significantly impact on organizational performance or partially affect. These are main hypothesis on the Basis of the conceptual framework;

1. Employee Engagement (EE) will significantly influence on organizational performance (OP).

2. Work force diversity (WFD) will have moderating impact on the relationship between Employee Engagement and Organizational Performance

\section{Review of Literature}

Engagement is a workplace approach designed to ensure that employees are committed to their organization's goals and values, motivated to contribute to organizational success, and are able at the same time to enhance their own sense of well-being (MacLeod \& Clarke, 2009). Accordingly, Rothwell (2010) described engagement as a positive attitude toward the job and distinguished it from both job satisfaction and commitment. Engagement is more temporary and volatile than commitment. It is all about passion and commitment. It is the willingness to invest oneself and expand one's discretionary effort to help the employer succeed, which is beyond simple satisfaction with the employment arrangement or basic loyalty to the employer. Thus, the complete equation of engagement is obtained by aligning maximum job satisfaction and maximum job contribution (Sharma \& Krishnan, June 2012).

As an independent concept, employee engagement can best be defined as a positive, fulfilling, work-related state of mind that is characterized by vigor, dedication and absorption (Schaufeli et al. 2002b). According to Schaufeli et al. (2002), vigor is characterized by high levels of energy and mental resilience while working, the willingness to invest effort in the work and persistence even in the face of difficulties. Personnel with vigor are characterized as a highly engaged employee.

Full engagement represents an alignment of maximum job satisfaction ("I like my work and do it well") with maximum job contribution ("I help achieve the goals of my organization"). Disengaged employees 'uncouple' themselves from their roles, suppressing personal involvement in physical, cognitive and emotional aspects of work (Truss, Shantz, 
Soane, Alfes, \& Delbridge, 2013). They are not just passionate or proud. They have a line-of-sight on their own future and on the organization's mission and goals. They are enthused and in gear, using their talents and discretionary effort to make a difference in their employer's quest for sustainable business success (GP Strategies, 2013).

Actively disengaged employees are more or less out to damage their company. They monopolize managers' time; have more on-the-job accidents; account for more quality defects; contribute to "shrinkage," as theft is called; are sicker; miss more days; and quit at a higher rate than engaged employees do. Whatever the engaged do - such as solving problems, innovating, and creating new customers - the actively disengaged try to undo. On the other hand, engaged employees are the best colleagues. They cooperate to build an organization, institution, or agency, and they are behind everything good that happens there. These employees are involved in, enthusiastic about, and committed to their work. They know the scope of their jobs and look for new and better ways to achieve outcomes. They are $100 \%$ psychologically committed to their work. And, they are the only people in an organization who create new customers."

\section{Research Gap}

Human resource management is the major issue on which every organization should put sufficient effort regularly. Employees may be committed towards their employing organization as well as assigned job but they may not have engaged enough. Getting their physical, mental and emotional effort at a time during the job accomplishment is really a hard and challenging job to the managers. But the question is that whether the organizations are able to engage the employees or not? What are the factors influencing the level of employee engagement? To which extent the influencing factors and level of engagement are related? Whether the demographic and organizational factors affect the engagement level or not?

Bhandari (2012) stated on his research that there was lack of research on the impact of employee motivation and commitment in public sector. Reward and other tangible motivational tools were considered as affecting factors of HR outcome in basically in Nepalese context. That is why, the study is aimed to address such meaningful relation of employee engagement which is being ignored as part of organizational behavior.

\section{Research Methodology}

The field survey is conducted to measure the perception of respondent in the study. Descriptive and analytical nature of this study depends on primary data that was collected from Tribhuvan University (TU). Convenience surveys are designed to generate the data with administering structured questionnaire. Each dependent and independent variables are constructed to obtain responses from employee. This study followed quantitative 
statistical technique to describe the relation of employee engagement and organizational performance with consisting of descriptive statistical tools; mean, standard deviation, normality and inferential statistical tools, correlation analysis and regression analysis.

As sample for organizational work groups, it was chosen to use employees from the Tribhuvan University (TU). The enterprise is chosen using Convenient sample techniques. In this sector, employee engagement strategies and organizational performance is quite different from other public and private organizations of Nepal. This enterprise is suffering from quality related problem in terms of qualitative product and service delivery. It observed that the level of employee engagement is low in this sector, basically in side of employee satisfaction. The employees were chosen from administrative and technical filed. In the study, 150 questionnaires were distributed to concern staff during March, April, May 2019 and out of them only 115 valid questionnaires were able to be collected. Only 77 percentage responses out of 150 distributed questionnaire was received. Using convenient sampling technique, heterogeneous employees were chosen from various campuses and offices from from TU.

This study is totally dependent on primary data that was collected from the employee of TU. Structured questions were set for retaining of the information from respondent through Likert scale concept. The study has used 5 point Likert Scale to express the extent of respondents' opinions that is generally prefer in Nepalese context especially in social behavior research. The questionnaire covered independent variables- employee engagement and dependent variable-organizational performance. The respondent's agreement or disagreement with the given statements was measured with Likert items with strongly agree to strongly disagreement. Structured questionnaire including three segmentations; 1) respondent details 2) questions items regarding to employee engagement 3) questions items including organizational performances constructions were placed in questionnaire.

This study is based on following diversity work group. Various age groups, positions, gender and nature of job of employee were selected as the respondent so as to make is draw inference over the demography variables. The gender composition of the respondent is presented in following table.

Table 3.1

Response to Questionnaire and Representation as Gender

\begin{tabular}{lcccc}
\hline Gender Status & Frequency & Percent & Valid Percent & Cumulative Percent \\
\hline Male & 76 & 66.1 & 66.1 & 66.1 \\
Female & 39 & 33.9 & 33.9 & 100.0 \\
Total & 115 & 100.0 & 100.0 & \\
\hline
\end{tabular}

Survey; $\mathrm{N}=115$ 
As per mention table, Male employee dominates the responses among the employee. 66.1 percentages was responded by male employee and 33.9 percentages was responded by female.

The age composition of the respondent is described as following Table

Table 3.2

Response to Questionnaire and Representation as Age of Employee

\begin{tabular}{lllll}
\hline Age Pattern & Frequency & Percent & Valid Percent & Cumulative Percent \\
\hline Below 25 & 2 & 1.7 & 1.7 & 1.7 \\
26 to 35 & 28 & 24.3 & 24.3 & 26.1 \\
$36-50$ & 43 & 37.4 & 37.4 & 63.5 \\
51 and above & 42 & 36.5 & 36.5 & 100.0 \\
Total & 115 & 100.0 & 100.0 & \\
\hline
\end{tabular}

Survey; $\mathrm{N}=115$

Age above 36 has play significant role in work place regarding to productivity of the organizations.

The tenure employee of the respondent is shown in following table

Table 3.3

Response to Questionnaire and Representation as Marital Status

\begin{tabular}{lllll}
\hline Status & Frequency & Percent & Valid Percent & Cumulative Percent \\
\hline Unmarried & 22 & 19.1 & 19.1 & 19.1 \\
Married & 91 & 79.1 & 79.1 & 98.3 \\
Other & 2 & 1.7 & 1.7 & 100.0 \\
Total & 115 & 100.0 & 100.0 & \\
\hline
\end{tabular}

Survey; $\mathrm{N}=115$

Tribhuvan University is also a kind of public enterprise this is why married employees are attracting, as a result, employee commitment seems high (Shrestha 2015).

Table 3.4

Education

Response to Questionnaire and Representation as Education Level

\begin{tabular}{lllll}
\hline Education Status & Frequency & Percent & Valid Percent & Cumulative Percent \\
\hline Bachelor and Above & 94 & 81.7 & 81.7 & 81.7 \\
Below Bachelor & 21 & 18.3 & 18.3 & 100.0 \\
Total & 115 & 100.0 & 100.0 & \\
\hline
\end{tabular}

Survey; $\mathrm{N}=115$ 
It tried to collect more responses from officer level because they feel actual work experiences. They need to work and interact formally and non-formally at decision making process and closely realize and feel manager's or campus chief's behavior, thus, those levels try to copy and follow the behavior to present obedient and dedication.

\section{Table 3.5}

\section{Working Area}

Response to Questionnaire and Representation as Nature of Job

\begin{tabular}{lllll}
\hline Job Nature & Frequency & Percent & Valid Percent & Cumulative Percent \\
\hline Technical & 18 & 15.7 & 15.7 & 15.7 \\
Administration & 97 & 84.3 & 84.3 & 100.0 \\
Total & 115 & 100.0 & 100.0 & \\
\hline Survey; Ne1 & & & &
\end{tabular}

Survey; $\mathrm{N}=115$

Employees were chosen for this study as their nature of job. Main target employees for the study is administrative staff, however, this study tries to identify response from technical staff as well. It shows that in administration, technical staffs also have been working.

All statements were coded for numerical treatment. Descriptive statistics, Correlation Analysis and regression analysis etc. tools are used to analysis the entered data. Descriptive statistics is taken to analyze the nature and variance of the data, demography pattern of data, separate and aggregate level of perceived level of impression management and degree of employee commitment. This study has carried out regression analysis by defining the statistical model whether impression management dimension influence as set of hypothesis on employee commitment or not.

Following statistical models are used to regress the two types of variables.

$\mathrm{Y}=\beta 0+\beta 1 \mathrm{X} 1+\mu$

$\mathrm{OP}=\beta 0+\beta 1 \mathrm{EE}+\varepsilon$

Where,

$\mathrm{OP}=$ Organizational Performance

$\mathrm{EE}=$ Employee Engagement

$\varepsilon=$ Random error term

\section{Data Presentation and Analysis}

Public enterprises in Nepal, being a direct entity of the government, have the same bureaucratic process of functioning as any other government office. Due to this reason along with the absence of clear objectives and goals, and with no mechanism for monitoring and evaluating these enterprises have not been able to perform to the best of their capacity. Main challenge for public enterprises in Nepal is centered on striking a balance between its commercial and non-commercial aspects which leads to problems with accountability 
and autonomy. Overall, one of the major challenges is tied to the incentive system that PEs as a whole faces as well as the incentives. Analysis of public enterprises indicates that they have become a huge burden to the Ministry of Finance, have been weakening the government's social position, have low return on investments and generally have poor quality of service, and limited range of delivery.

Rational of selecting TU as a sample organization of the case study is that the university has to face intense competition with national universities and international universities and education institutions and also need to cope with environmental dynamism regarding to quality education and innovativeness. There are 15,196 employees has been working in this university including teachers, instruction, administration and support staff. Main thing is that TU has decreasing its quality and creativeness and production of TU (students) has been reducing employee opportunities in the market and also competency and commitment of employee cannot be well managed in order to get sustainable competitive advantage..

Several HR practice and policy have been practicing in PSO since many years to motivate the employee and enhance the engagement level within an organization. Hence, in this situation it is interesting and fruitful to explore the different factor that can add the extra foundation to create employee engagement in PSE.

In an organization, work force diversity in terms of gender, age, employee level and job nature are widely found. In this era of an increasingly work force-diverse workforce, understanding the social factors that impact diversity relations and dynamics is critical. Perceive of commitment towards organization by influencing from other behavior may be differ as their gender, age, level of employee and job nature of employees' in PSE. The commitment nature by work force diversity can be described as given table;

Table No. 4.1

Employee Engagement and Its Descriptive Analysis

\begin{tabular}{|c|c|c|c|c|c|c|c|c|c|c|c|c|c|c|}
\hline \multirow{2}{*}{$\begin{array}{l}\text { Items descriptions of } \\
\text { Employee Engagement }\end{array}$} & \multicolumn{4}{|c|}{ Age of EmployeeG } & \multicolumn{2}{|r|}{ enderE } & \multicolumn{2}{|c|}{ Marrital StatusY } & \multicolumn{4}{|c|}{ ears of joining orgnization } & \multicolumn{2}{|c|}{ ducation } \\
\hline & $\begin{array}{c}\text { Below } \\
25\end{array}$ & $\begin{array}{c}26 \text { to } \\
35\end{array}$ & $\begin{array}{c}36- \\
50\end{array}$ & $\begin{array}{l}51 \text { and } \\
\text { above }\end{array}$ & Male & Female & UnmarriedM & arried & $\begin{array}{l}1 \text { to } 5 \\
\text { years }\end{array}$ & $\begin{array}{l}6 \text { to } 10 \\
\text { Years }\end{array}$ & $\begin{array}{l}11 \text { to } 15 \\
\text { years }\end{array}$ & $\begin{array}{l}\text { More } \\
\text { than } 15 \\
\text { Years } \\
\end{array}$ & $\begin{array}{l}\text { Bachel } \\
\text { or and } \\
\text { Above }\end{array}$ & $\begin{array}{l}\text { Below } \\
\text { Bachelor }\end{array}$ \\
\hline $\begin{array}{l}\text { I know what is expected of me } \\
\text { at work. }\end{array}$ & 4.00 & 3.50 & 4.21 & 4.05 & 3.87 & 4.18 & 3.64 & 4.05 & 3.17 & 3.88 & 4.41 & 4.03 & 3.97 & 4.00 \\
\hline $\begin{array}{l}\text { My working environm ent is } \\
\text { exciting to work. }\end{array}$ & 4.00 & 3.50 & 3.58 & 3.81 & 3.71 & 3.54 & 3.82 & 3.60 & 3.67 & 3.50 & 3.65 & 3.69 & 3.66 & 3.62 \\
\hline $\begin{array}{l}\text { People in mywork group } \\
\text { cooperate with each other to } \\
\text { get the job done. }\end{array}$ & 4.00 & 3.79 & 4.07 & 3.81 & 3.84 & 4.03 & 3.73 & 3.92 & 3.83 & 4.00 & 3.593 & .973 & .983 & .57 \\
\hline $\begin{array}{l}\text { My work directly contributes to } \\
\text { the overall success of the } \\
\text { organization. }\end{array}$ & 4.00 & 4.29 & 4.49 & 4.29 & 4.32 & 4.44 & 4.27 & 4.38 & 4.33 & 4.38 & 4.29 & 4.37 & 4.41 & 4.10 \\
\hline $\begin{array}{l}\text { I am satisfied with mysalary } \\
\text { and benefits. }\end{array}$ & 2.00 & 3.573 & .603 & .433 & .473 & .563 & .363 & .533 & .333 & .634 & .293 & .313 & .523 & .43 \\
\hline
\end{tabular}




\begin{tabular}{|c|c|c|c|c|c|c|c|c|c|c|c|c|c|c|}
\hline $\begin{array}{l}\text { Mys enior always treats me } \\
\text { with respect. }\end{array}$ & 4.00 & 3.57 & 4.26 & 4.10 & 3.95 & 4.18 & 3.55 & 4.12 & 4.00 & 3.75 & 3.82 & 4.14 & 4.09 & 3.76 \\
\hline $\begin{array}{l}\text { Job assigned allows me to } \\
\text { use mybest skills. }\end{array}$ & 4.00 & 4.00 & 4.26 & 4.05 & 4.11 & 4.13 & 4.09 & 4.14 & 3.83 & 4.00 & 4.53 & 4.09 & 4.13 & 4.05 \\
\hline $\begin{array}{l}\text { I receive feedback that helps } \\
\text { me improve myperformance. }\end{array}$ & 4.00 & 3.79 & 4.26 & 4.33 & 4.21 & 4.08 & 4.18 & 4.16 & 4.17 & 3.75 & 4.18 & 4.26 & 4.22 & 3.90 \\
\hline $\begin{array}{l}\text { Employee performance } \\
\text { evaluations are fair and } \\
\text { appropriate. }\end{array}$ & 2.00 & 3.79 & 3.44 & 3.76 & 3.63 & 3.59 & 3.64 & 3.63 & 3.67 & 3.63 & 3.65 & 3.60 & 3.67 & 3.38 \\
\hline $\begin{array}{l}\text { I have sufficient materials and } \\
\text { information I need to do my } \\
\text { job well. }\end{array}$ & 2.00 & 3.29 & 3.67 & 3.48 & 3.47 & 3.49 & 3.09 & 3.56 & 2.83 & 3.38 & 4.00 & 3.49 & 3.49 & 3.43 \\
\hline $\begin{array}{l}\text { I am comfortable sharing my } \\
\text { opinions at work. }\end{array}$ & 4.00 & 3.50 & 4.26 & 4.10 & 3.95 & 4.13 & 3.55 & 4.12 & 3.50 & 3.63 & 4.18 & 4.14 & 4.01 & 4.00 \\
\hline $\begin{array}{l}\text { My workplace is physically } \\
\text { comfortable to work. }\end{array}$ & 4.00 & 3.79 & 3.86 & 4.00 & 3.87 & 3.95 & 3.45 & 4.00 & 3.17 & 4.13 & 4.00 & 3.94 & 3.87 & 4.00 \\
\hline $\begin{array}{l}\text { Myideas and opinions count } \\
\text { at work. }\end{array}$ & 4.00 & 3.86 & 4.09 & 4.10 & 4.05 & 4.00 & 3.82 & 4.11 & 3.83 & 3.75 & 4.24 & 4.09 & 4.03 & 4.05 \\
\hline $\begin{array}{l}\text { People trust each other in my } \\
\text { work group. }\end{array}$ & 4.00 & 4.00 & 4.02 & 3.95 & 3.95 & 4.08 & 3.82 & 4.03 & 4.00 & 4.00 & 3.94 & 4.00 & 3.97 & 4.10 \\
\hline $\begin{array}{l}\text { At myjob, I feel strong and } \\
\text { energetic. }\end{array}$ & 4.00 & 3.79 & 4.44 & 4.19 & 4.08 & 4.38 & 3.82 & 4.27 & 4.17 & 3.75 & 4.29 & 4.26 & 4.27 & 3.81 \\
\hline $\begin{array}{l}\text { I feel encouraged to come up } \\
\text { with new and better ways of } \\
\text { doing things. }\end{array}$ & 4.00 & 3.71 & 4.02 & 4.14 & 3.92 & 4.13 & 3.91 & 4.03 & 4.00 & 3.75 & 4.06 & 4.03 & 4.00 & 3.95 \\
\hline I am satisfied with myjob. & 4.00 & 4.14 & 4.16 & 4.05 & 3.95 & 4.44 & 4.00 & 4.14 & 4.00 & 4.25 & 4.18 & 4.09 & 4.14 & 4.00 \\
\hline $\begin{array}{l}\text { It is difficult to detach myself } \\
\text { from myjob. }\end{array}$ & 4.00 & 3.71 & 3.63 & 3.57 & 3.58 & 3.74 & 3.18 & 3.76 & 3.83 & 3.75 & 3.65 & 3.57 & 3.61 & 3.76 \\
\hline $\begin{array}{l}\text { People in my work group } \\
\text { quickly resolve conflicts when } \\
\text { arise. }\end{array}$ & 4.00 & 4.07 & 4.07 & 3.76 & 3.84 & 4.18 & 4.00 & 3.95 & 4.17 & 4.13 & 3.94 & 3.89 & 3.95 & 4.00 \\
\hline $\begin{array}{l}\text { I would recommend } \\
\text { employment at my } \\
\text { organization to my friends } \\
\text { and families. }\end{array}$ & 4.00 & 4.07 & 3.86 & 3.76 & 3.84 & 3.95 & 3.73 & 3.91 & 4.33 & 4.13 & 3.65 & 3.80 & 3.96 & 3.52 \\
\hline Average form of Response & 3.70 & 3.79 & 4.01 & 3.94 & 3.88 & 4.01 & 3.73 & 3.97 & 3.79 & 3.86 & 4.03 & 3.94 & 3.95 & 3.82 \\
\hline
\end{tabular}

Survey; $\mathrm{N}=115$

Above table demonstrates that employee of TU is engaged. Similarly Female employee is more engaged than male employee with having 4.01 mean values. Among the variables, male and female both presented their high agreement on the statement "At my job, I feel strong and energetic."

In University, most likely job tenure in between 10 years to 15 years employee seems high engaged. It states that after working 10 years in same organization, it raises level of engagement towards that organization. It reveals that older the age group, lesser is the engagement towards the organization same as younger group of employee has less employee engagement than adult age group. The age between 36 to 50 is more engaged because this age group is more productive group at public organization (Shrestha, 2015) and it has more employee commitment with job satisfaction. But for the case "My working 
environment is exciting to work." all age group are less agreed. Thus, TU immediately needs to recover the work place as comfortable for concern employee.

Education of employee also influences to engagement level, higher the education higher engagement towards work (Damoder, 2016). It supports prior theory of employee engagement since average mean of graduate employee is greater than average mean of non graduate employee. This means higher level of education persuades to do job willingly. The data also revels that no significance difference between married and unmarried employee in the theme of employee engagement.

Data seems to be reliable and consistency for further analysis since having Cronbach value is 0.761 that is higher the value of satisfactory point 0.70 which indicates employee engagement items are reliable. Among 20 statements, 5 statements need to eliminate since it did not seem consistency with other statements. Thus, altogether 15 variables are retained for further analysis as independent variables.

\section{Normality Test of Employee Engagement}

This table is formulated to confirm whether or not the scale values are normally distributed, before further analysis.

Table No. 4.2

One-Sample Kolmogorov-Smirnov Test

Sum of Employee Engagement

Number of case

115

Normal Parameters ${ }^{\mathrm{a}, \mathrm{b}}$ Mean

29.0816

Std. Deviation

5.48279

Most

Extreme Absolute

.188

Differences

Positive

.106

Negative

$-.188$

Kolmogorov-Smirnov Z

3.153

Asymp. Sig. (2-tailed)

.000
a. Test distribution is Normal.
b. Calculated from data.

$\mathrm{K}-\mathrm{S}$ test confirms that the data is normally distributed at $1 \%$ level of significance, since sig value $=0.000$. Annex I also supports the condition of normality. The optimum sum scale of employee engagement seems to be normally distributed as symmetric distribution.

Organizational performance is constructed in this study with questionnaire survey. Likert rating scale was used to get level of agreement towards the impression behavior of the senior. It has employed 10 likert items as organizational performance. It demonstrates that 
all items have more mean value indicating the higher perceive rate of OP behavior in PSE that is persuaded by

The descriptive analysis of individual items, tactics of OP and whole EE domains. All statements have more than two scores that means respondent response agree version towards those statements. Similarly aggregate mean value is 4.25 which indicate that most of employees of PSO feel organization performance is dependent variable.

It is confirmed before reliability test that all the items were scored in the same direction i.e. mean value is greater than 2 scores. It ensures that respondent really read and understands the item before they respond. Internal reliability of a 10 item scale is assessed using Cronbachs' alpha technique. One items (Q10; I help others in this organization whenever I can) needed to be deleted since it did not content favorable result. As the scale produced an alpha of 0.836 , which is acceptable for an attitude scale, it can be proceeding for further analysis to confirm whether these dimensions of OP are fixed in Nepalese context as per literature in western countries.

\section{Employee Engagement and Organizational Performance}

This test aims to find out impacts of employee engagement on organizational performance. Organizational performance is likely to improve by enhancing employee engagement. Once employees are engaged they willingly feel ownership toward the organization and internalize the organizational objectives and also wanted to stay as a part of the organization. Then after, employee reflects positive attitudes towards the job and ready to provide extra efforts for the job. That is why, impression engagement is based on the emotional attachment behavior of an organization.

The model used to test the relations between employee engagement and organizational performance variable is;

$\mathrm{Y}=\beta 0+\beta 1 \mathrm{X} 1+\mu$

$\mathrm{OP}=\alpha+\beta 1 \mathrm{EE}+\varepsilon$

Where,

$\mathrm{EE}=$ Employee Engagement

$\mathrm{OP}=$ Organizational Performance

$\varepsilon=$ Random error term

Following table explains how impression engagement influence and in what extends it impacts on organizational performance of employee of PSO. 
Table No. 4.3

\section{Correlation Between Employee Engagement and Organizational Performance}

Correlations

\begin{tabular}{lccc} 
& & EE & OP \\
\hline EE (Sum of Scale of Employee & Pearson & 1 & $.698^{* *}$ \\
Engagement ) & Correlation & & \\
& Sig. $(2$-tailed) & & .000 \\
& $\mathrm{~N}$ & 115 & 115 \\
OP (Organizational Performance) & Pearson & $.698^{* *}$ & 1 \\
& Correlation & & \\
& Sig. (2 -tailed) & .000 & \\
& $\mathrm{~N}$ & 115 & 115
\end{tabular}

**. Correlation is significant at the 0.01 level (2-tailed).

Above correlation matrix presents that the variables within the variables are strongly correlated. According to the mention results and findings, it can conclude that the perceptions regarding to employee engagement and organizational performance.

\section{Table No. 4.4}

\section{Regression Result of Employee Engagement on Organizational Performance}

Coefficients

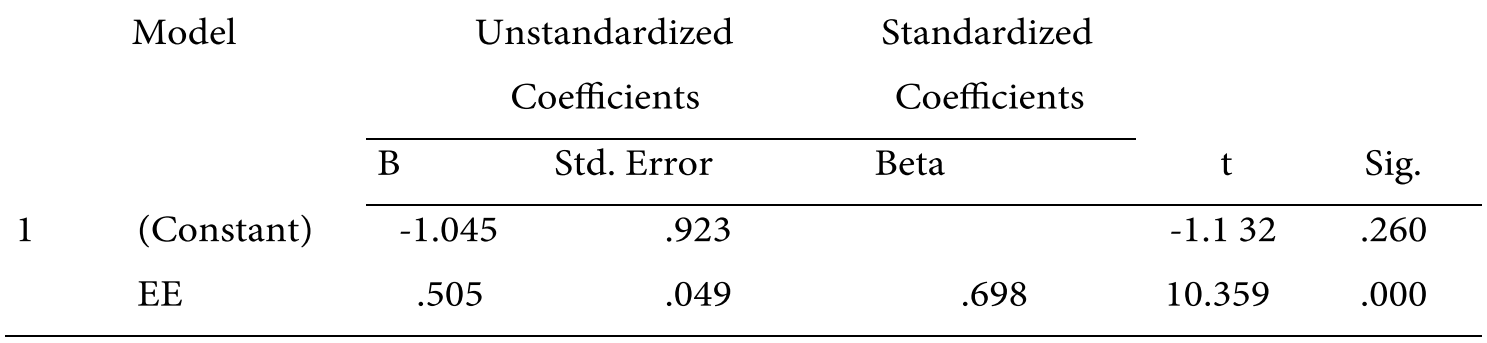

a. Dependent Variable: $\mathrm{OP}$

$\mathrm{F}=107.37, \mathrm{P}_{-}$Value $=0.000 \mathrm{R} 2=0.49$ and adjusted $\mathrm{R} 2=0.48$

$\mathrm{OP}=\alpha+\beta 1 \mathrm{EE}+\varepsilon$

$\mathrm{Op}=-1.045+0.505+0.04$

As shown table, the constant term is -1.045 which reveal that the organizational performance remains at least -1.045 points irrespective of employee engagement. It reveals that 1 unit increase in such EE leads to organizational performance by 0.505 points. 
Overall model seems to be best since p_value of $\mathrm{f}$ _test lesser than 0.05 ( $\mathrm{sig}=0.000)$. Thus every variable helps to explain the dependent variables. A coefficient is significant. Employee Engagement explains $0.505(50 \%)$ on organizational Performance, thus, employee engagement somehow influence on organizational performance.

\section{Results and Discussion}

1) Objective of the study is to examine the relationship of employee engagement with organizational performances. For this purpose, altogether 30 questionnaires were administered, using 5 Points Likert rating scale survey questionnaires were administered. The response rate of return of questionnaires is 76.67 percentages.

2) The table presents the status and nature of responses. Overall mean value of all items is 3.92. Among the statements, "My work directly contributes to the overall success of the organization." (EE 45.3) has highest mean value of 4.36 with standard deviation 0.55 and the statement "I am satisfied with my salary and benefits." (EE 5) least mean value 3.5 with standard deviation 0.98 .

3) Average response of employees on engagement variables is 3.199 with standard deviation of 0.674 . The variable "I help others in this organization whenever I can" has the highest mean score 3.440 with standard deviation of 0.560 and the least score is 2.77 with 0.766 standard deviation of the variable "It is difficult to detach myself from my job".

4) It seems that Female employee is more engaged, however, female seems to be less committed, in case of the statement "I have sufficient materials and information", since its mean value is 3.49 , meaning that female employee is not feeling that they have adequate office materials and simultaneously they are well informed.

5) Job tenure in between 10 years to 15 years employee seems highly engaged. It also indicates that after 15 years working in same pattern, engagement goes to downwards because it increases monotonous as theory of law of diminishing. The data revels that age between 36 to 50 is more engaged. Age group in between 36 to 50 is more productive group at public organization (Shrestha, 2015) and it has more employee commitment with job satisfaction. But for the case "My working environment is exciting to work." all age group are less agreed.

6) Education of employee also influences to engagement level, higher the education higher engagement towards work (Damoder, 2016). It supports prior theory of employee engagement since average mean of graduate employee is greater than average mean of non graduate employee. 
7) Data seems to be reliable and consistency for further analysis since Cronbach value is 0.761 after eliminating 5 statements. Similarly, K-S test confirms that the data is normally distributed at $1 \%$ level of significance, since sig value $=0.000$.

8) Correlation presents that variables are strongly correlated. Overall model seems to be best since p_value of $\mathrm{f}$ _test lesser than 0.05 (sig=0.000). Thus every variable helps to explain the dependent variables. Employee Engagement explains 0.505(50\%) on organizational Performance, thus, employee engagement influences on organizational performance in some extent.

\section{Conclusion}

This study has been undertaken to indentify impacts of employee engagement on organizational performance. The relationship of different work force diversities has also been observed. It shows younger worker has less responded which is similar to prior research that "employee engagement concerns are probably more salient to younger workers, compared to older workers, because of their relative lack of experiences at work" (Singer \& Sewell, 1989). On the basis of mean responses, it can be concluded that younger and older age group of employee presents less.

It was hypothesized that Employee Engagement (EE) will significantly influence on organizational performance. and Work force diversity (WFD) will have moderating impact on the relationship between Employee Engagement and Organizational Performance. As control variable, it was included work force diversities. During the analysis, the hypotheses were supported. Employee engagement explains with 0.505 (50 percentages) on employee commitment, and since they are correlated with 0.696 , thus, Employee Engagement somehow influence on Organizational performance. Cheng, Chiu, \& Tzeng (2013) clearly stated that an employee, who are engagement, can understand social cues among the others thus he/she can choose the way to improve social skills in order to achieve organizational goals. Şebnem and Akarçay (2014), on their study mentioned that the significant relation between organizational performance and employee engagement was found.

In conclusion, the study contributed to the literature of employee engagement by investigating its relationship with organizational performance in Nepalese context. The result provides evidence that employee engagement and performance are significantly related. Management and human resource professionals need to comprehend the importance of employee engagement for the effective functioning of the organization and find way of enhancing employee commitment.

Future studies that encompass other antecedent of employee engagement should carried out within different work setting in order enrich literature on human resources 
management. This research stimulates researchers to begin to think about how employee engagement relates to HR outcome and contribute to the enhancement of organizational outcomes and organizational culture.

\section{Implication}

Organization with engaged employees have higher employee retention as a result of reduced turnover and reduced intention to leave the company, productivity, profitability, growth and stakeholder's satisfaction. On the other hand, companies with disengaged employees suffer from waste of effort and bleed talent, earn less commitment from the employees, face increased absenteeism and have less customer orientation, less productivity, and reduced operating margins and net profit margins (Markos \& Sridevi, 2010). To achieve these benefits, companies should always try to make employees engaged and transform not engaged and disengaged employees to engaged ones. By implementing the identified engagement determinants, TU can be benefited in terms of employee engagement. TU should always try to make employees' perception positive toward these determinants.

The future researcher can have an attempt to test relationship between these components in other public and large service nature organizations where service is directly provided by employee.

\section{References}

Adhikari, D. R., \& Gautam, D. K. (2011). Employees' commitment and organizational performance in Nepal: A typological framework. SEBON Journal , 1-17.

Bhandari, Kedar Prasad, (2010). Reward System and employee commitment; A study of Nepalese public sector bank. Unpublished MPhil thesis, faculty of management, Tribhuvan University.

Chat-Uthai, M. (2013). Leveraging Employee Engagement Surveys Using the Turnover Stimulator Approach: A Case Study of Automotive Enterprises in Thailand. Inter national Journal of Business and Management, 8 (6), 16-21.

Cheng, J.-W., Chiu, W.-L., \& Tzeng, G.-H. (2013). Do Impression Management Tactics and/or Supervisor-Subordinate Guanxi Matter? Knowledge-Based Systems, 40, 123-133.

Damodar Niraula, (2015). Employee Engagement in Media Sector. Unpublished MPhil thesis, Faculty of Management, Tribhuvan University, Kirtipur, 2015

Gallup Incorporation. (2013). State of the American workplace: Employee engagement ensights for U.S. business leaders. Gallup Incorporation. 
GP Strategies. (2013). Employee engagement research update. BlessingWhite. BlessingWhite.

Harter, J. K. (2002). Business-unit-level relationship between employee satisfaction, employee engagement, and business outcomes: a meta-analysis. Journal of Ap plied Psychology, 87 (2), 268-279.

Inceoglu, I., \& Fleck, S. (2010). Engagement as a motivational construct. In S. Albrecht (Ed.) The handbook of employee engagement: Models, measures and practices (pp. 74-86). Cheltenham UK Elgar.

Little, B., \& Little, P. (2006). Employee Engagement: Conceptual Issues. Journal of Or ganizational Culture, Communications and Conflict , 10 (1), 111-120.

M.S Singer, Christine Sewell , (1989), Applicant Age and Selection Interview Decision. Personal Psychology. Volume 4, Issue 1 page 135-154

Macey, W.H., \& Scheider, B. (2008). The Meaning of Employee Engagement. Industrial and Organizational Psychology, 1, 3-30.

Markos, S., \& Sridevi, M. S. (2010). Employee Engagement: The Key to Improving Performance. International Journal of Business and Management , 5 (12), 89-96.

Rothwell, N. (2010). The engaged university. A manifesto for public engagement. Retrieved from https://www.publicengagedment.ac.uk

Schaufeli, W. B., Salanova, M., Gonzalez-Roma, V., \& Bakker, A. B. (2002). The measurement of engagement and burnout: a two sample confirmatory factor analytic approach. Journal of Happiness Studies , 3 (1), 71-92.

Sebnem and Akarcay, (2014). The Effects of Impression Management and Organizational Affective Commitment on Citizenship Performance. The Clute Institute International Academic Conference, German.

Sharma, D., \& Krishnan, V. R. (June 2012). The Impact of Pay Satisfaction and Transformational Leadership on Employee Engagement. 5th International Conference of Management and Behavioural Sciences. Haridwar, India.

Shepherd, J. L., \& Mathews, B. P. (2000). Employee Commitment: academic vs practitioner perspectives. Employee Relations , 22 (6), 555-571.

Shrestha, Rupa (2015), Impression Management and Employee Commitment: Public Service Sector in Nepal" The Nepalese Management Review, Central Department of Management, Tribhuvan University, Kirtipur, 2017. 
Shuck, B. \& Reio, T., (2011). The employee engagement landscape and HRD: How do we link theory and scholarship to current practice, Advances in Developing Human Resources, 13(4), 419-428.

Soni, B. S. (2013). Employee Engagement - A Key To Organizational’ Success In 21st Century. Voice of Research , 1 (4), 51-55.

Towers Watson. (2010). Turbocharging Employee Engagement: the Power of Recognition from Management. Part 1 - The Engagement Engine. Research Report. April 2009.

Towers Watson. (2012). Global Workforce Study: Engagement at Risk: Driving Strong Performance in a Volatile Global Environment . Towers Watson.

Truss, C., Shantz, A., Soane, E., Alfes, K., \& Delbridge, R. (2013). Employee engagement, organisational performance and individual well-being: exploring the evidence, developing the theory. The International Journal of Human Resource Management , 24 (14), 2657-2669.

U.S. Merit Systems Protection Board. (2008). Managing for Engagement Communication, Connection, and Courage. Research Report, Washington, D.C. 